\title{
VERBO-VISUAL RHETORIC OF BELFAST MURALS
}

\begin{abstract}
Belfast murals are one of the landmarks of the city. They constitute a peculiar medium of communication, mixing word and image in a powerful ideological message. They express highly emotional content, and have been addressed to original target audiences of republicans and loyalists. In this respect they have served to reflect and influence sentiments of the communities involved in the conflict, and as a communal memoir commemorating crucial events, thereby contributing to their ethnic identity formations. However, as Northern Ireland has been undergoing the peace process, the murals are becoming one of the city's tourist attractions. As such, they are encountered by audiences unaware of intricacies and nuances of local history. This paper examines how their complex verbo-visual rhetoric affects this type of audience, and how, in a reciprocal process, political tourism may have an impact on the murals' style and content.
\end{abstract}

Keywords: Belfast murals, word and image, verbo-visual rhetoric, dark tourism

\section{First sight}

My first encounter with Belfast murals occurred in 2010 in connection with a conference held at the University of Ulster. The organisers arranged a semi-formal tour of the city for a small, interested party. However, it wasn't listed in the programme, only advertised by word of mouth because, as we were told later, there were some qualms about showing us the contentious heritage. That was understandable, given the touchiness of the contents which the murals expressed, though slightly surprising, too, since they had been mentioned as a tourist attraction already in the early 1990's. ${ }^{1}$ In 1992 the Rough Guide to Ireland suggested that they were worth seeing. ${ }^{2}$ By 2000's the city was "routinely mentioned alongside Edinburgh, Manchester, and

1 B. Rolston, "Selling tourism in a country at war", Race \& Class, 1.07.1995, vol. 37(1), pp. 23-40, https://doi.org/10.1177/030639689503700103.

2 D. Lisle, "Local symbols, global networks: Rereading the murals of Belfast", Alternatives: Global, Local, Political, vol. 31(1), January-March 2006, pp. 27-28. See also N. Jarman, Painting Landscapes: The Place of Murals in the Symbolic Construction of Urban Space, the CAIN Project, University of Ulster, http://cain.ulst.ac.uk/bibdbs/murals/jarman.htm. 
Newcastle as a desirable tourist destination," 3 with mural trips featured among recommendations. Interested visitors could choose to look at them from a bus going along the most notorious mural locations, or they could hire a taxi with the driver acting as a guide, or even take a walk. ${ }^{4}$ Over a decade since the Good Friday Agreement of 1998, murals appeared to be a staple item on the list of "must-see" Belfast sights. ${ }^{5}$ It is thanks to them that the city has become one of the most renowned places for "dark", "war" or "political"" tourism.

The former term refers to visiting sites of death, disaster, and atrocities when tragic events are remembered by "those still alive to validate them". ${ }^{8}$ Such tourism is motivated by somewhat morbid curiosity, stimulated by modern communication technologies that make reporting on tragic events widely possible and almost instantaneous. It is also driven by a desire to understand and interpret them for oneself, especially that they pose a challenge to rationality, order, and belief in progress. ${ }^{9}$ For local communities, in turn, dark tourism offers an opportunity to revitalise the economy, admittedly at the price of commodifying their painful past. Incidentally, this may bring about other welcome effects, for example, when local people acting as guides begin to cross invisible boundaries and appear in areas they would be too afraid to visit in other circumstances. ${ }^{10}$ Related to this is what Debbie Lisle names "war" tourism, a variant of dark tourism, when not only historical battlefields but also locations of recent, brutal conflicts are becoming sightseeing attractions. As regards Belfast, Lisle notes that it constitutes an especially interesting case of "political" tourism "because visiting the murals in situ offers that 'coveted brush with danger' alongside the cosmopolitan and urban amenities expected in a small European city." 11

D. Lisle, “Local symbols...”, p. 43.

4 See D. Barry in "Belfast Journal; Murals of 'Troubles' Draw Passions, and Tourists" quoting Mr. Reilly, a driver in Black Taxi Tours (The New York Times, 12.08.2000). See also S. Calder, M. Gerry, "48 hours in Belfast, Northern Ireland", The Independent, 28.10 .2006 (https://www.independent. co.uk/travel/48-hours-in/belfast-northern-ireland-5331043.html [access: 4.09.2018]). As of 2018 there are a standard hop-on hop-off double-decker bus service, and dedicated Black Cab Tours, during which a "tour guide will expertly and impartially explain how the murals help to tell the story of the Northern Ireland conflict and how [the community] arrived at the current peace process" (Taxi Trax, Official Belfast Taxi Tours Website, http://taxitrax.com/belfast-mural-taxi-tours/).

5 See, e.g. Bitten by the Travel Bug blog by Nicole, "First Time in Belfast? 5 Must See Sites", 15.06.2012, https://bittenbythetravelbug.com/first-time-in-belfast-five-must-see-sites/ [access: 2.12.2018].

6 J. Lennon, M. Foley, Dark Tourism: The Attraction of Death and Disaster, New York: Continuum, 2000.

7 D. Lisle, Holidays in the Danger Zone: Entanglements of War and Tourism, Minneapolis: University of Minnesota Press, 2016, p. 127.

8 J. Lennon, M. Foley, Dark Tourism..., pp. 3-12.

$9 \quad$ R. Sharpley, "Shedding light on dark tourism: An introduction", [in:] R. Sharpley, P.R. Stone (eds.), The Darker Side of Travel: The Theory and Practice of Dark Tourism, Bristol, Buffalo \& Toronto: Channel View Publications, 2009, pp. 4-7.

$10 \quad$ N. Jarman, Painting Landscapes...

11 D. Lisle, "Local symbols...", p. 43. 
Our party went in a hired van. The guide was Bill Rolston, professor of sociology at the University of Ulster, one of the leading experts on the remarkable Ulster mural culture, ${ }^{12}$ who had been photographing and researching the phenomenon for decades. ${ }^{13} \mathrm{He}$ was also one of the first scholars who paid attention to the potential of murals for stimulating tourism in the troubled region. ${ }^{14} \mathrm{He}$ led us through what initially seemed monotone, working-class residential areas. Passing through Ardoyne Avenue, Shankill Road, Hopewell Crescent, Falls Road, Sandy Row, Albertbridge Road, and Newtownards Road, we saw rows of low, ordinary houses which gradually revealed to our company an amazing street gallery of vivid images. They were painted on gable walls, brick fences, and high, long walls separating loyalist and republican neighbourhoods. As we were encountering more and more of the images, it became clear why there was so much wariness about our trip.

\section{A Closer Look}

The murals were large, vivid, brightly coloured. Those depicting historical events such as the siege of Derry, the 1641 rising, the hedge school scene, hunger strikers of the 80 's, or international themes used a whole range of hues. Others used limited sets of colours: red, white, blue and black; or shades ranging from red through orange to yellow, green, and white; sometimes sepia or just black and white. The central element was typically a large human figure (in the vast majority of instances a man) or several people, though in some cases the centre was occupied by an emblem. It was accompanied by smaller elements such as flags, coats of arms, emblems, banners, sashes, floral motifs, and guns. The background was either a realistic or a schematic representation of the city: a street, houses, cars, public building. Alternatively, it was plain, one colour background. Occasionally, when a mural depicted a historical event, the background was landscape. Some compositions were enclosed in straight or ornamental frames, the latter usually embellished by inserts: also flags, emblems, floral motifs, birds, and words. Most images included text. It could be minimal: just a date or a name, a short slogan, a sentence. Or it could be a whole paragraph; then, it was the central element in a mural, on par with a person depicted in the image. Sometimes longer passages (usually quotations) appeared on the brick fences adjacent to the gable wall with a purely iconographic mural. Typefaces varied in style. There were sim-

12 Though Belfast is the most notorious for them, murals can be also found in other locations, such as Derry or Carrickfergus, and also inside the Long Kesh prison (otherwise called the Maze), where republican and loyalist fighters were imprisoned during the Troubles, and where they also painted murals.

13 Bill Rolston's publications on the subject include the series of photo books Drawing Support 1-4 (1992, 1993, 2003, and 2013 respectively), the monograph Politics and Paintings: Murals and Conflict in Northern Ireland, London \& Cranbury: Fairleigh Dickinson University Press, 1991, and numerous journal articles. For his bibliography of the subject see his website: https://billrolston.weebly.com/. B. Rolston, "Selling tourism...", pp. 23-40. 
ple, large block letters in sans serif fonts; such were texts usually conveying a threat or warning. Or on the contrary, the lettering could be ornamental Gothic or Gaelic type, used for single words, slogans, mottos, or longer passages. It was discernible that murals could be grouped into distinct visual styles coordinated with their themes: mytho-historiographic, militant-emblematic, universal-symbolic.

They made a strong impression on all of us. Their initial impact relied on an almost visceral response to their complex verbo-visual rhetoric. We felt: amazed, overwhelmed, stunned, sometimes moved, sometimes uneasy, alert, if not apprehensive, or even threatened. It was evident that murals were intended to send a powerful message to anyone out there, in the streets but at first we were hardly able to understand what exactly they "wanted" from us. ${ }^{15}$ Although we were aware of the painful conflict tearing the region, we did not understand much of local symbolism, or could not decode acronyms, nor discern subtle differences between organisations they stood for. Yet we could intuitively read the appeal to emotions and sentiments. Our guide gave his commentary after we had inspected them in silence, providing us with explanations concerning events, people, historical details, and symbols featured in the pictures. He also mentioned, in passing, how in his youth he could not even imagine walking so freely in places we were visiting now, which is in tune with Jarman's above quoted observation.

Evidently, due to their conspicuous size and distinct colouring they were used to mark and delimit territories of particular groups, republican and loyalist, a phenomenon already described in the literature of the subject. ${ }^{16}$ The space could be also marked by painting curbs and road posts so colours were in fact cultural codes: red, white and blue for pro-British loyalists or unionists; green, orange and white for republican or nationalists. This territorialisation was perhaps most explicitly expressed in an austere mural that featured large black capital letters covering a whole yellow gable wall: "YOU ARE NOW ENTERING LOYALIST SANDY ROW HEARTLAND OF SOUTH BELFAST ULSTER-FREEDOM FIGHTERS. QUIS SEPARABIT." Since then the background has been repainted in blue, as the photo below testifies (Fig. 1), which means that the mural is still preserved and used in this capacity.

15 To paraphrase the title of W.J.T. Mitchell's book What Do Pictures Want? The Life and Love of Images, Chicago \& London: Chicago University Press, 2005.

16 M. Forker, J. McCormick, "Walls of history: the use of mythomoteurs in Northern Ireland murals", Irish Studies Review 2009, vol. 17(4), p. 424. For more details see F. Boal, N. Douglas, Integration and Division: Geographical Perspectives on the Northern Ireland Problem, London: Academic Press, 1982. 


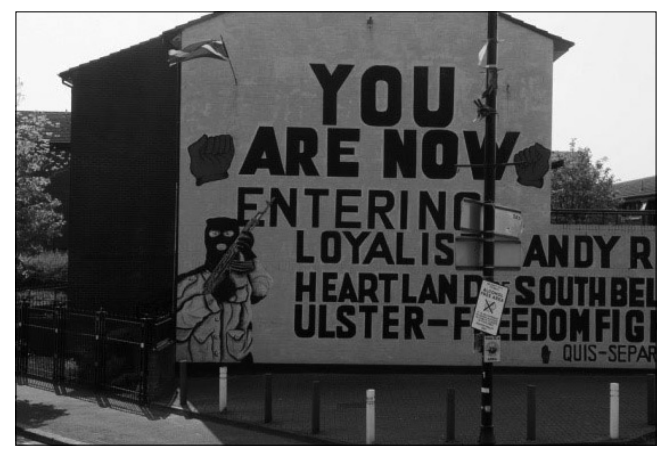

Fig. 1

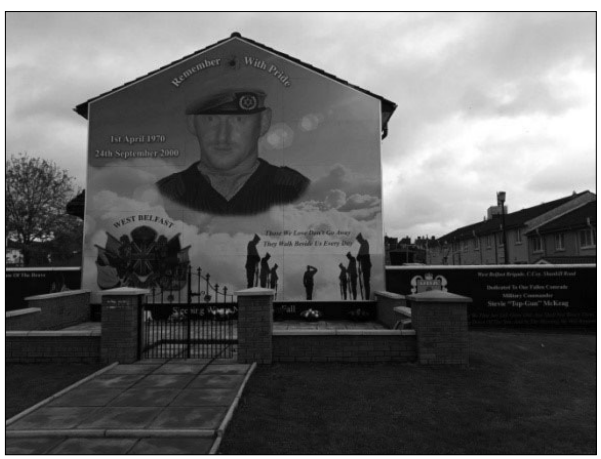

Fig. 3



Fig. 2

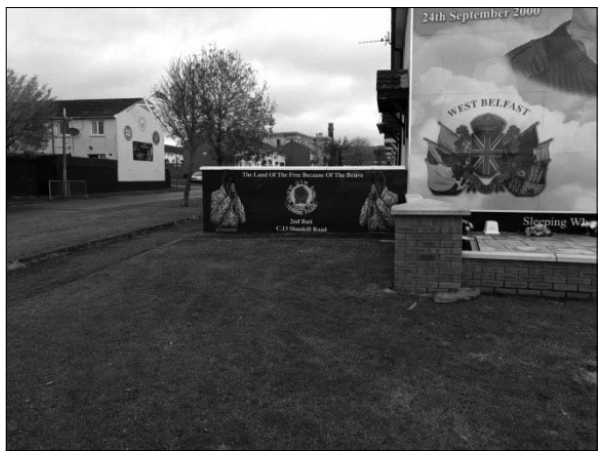

Fig. 4

The loyalist murals we saw usually contained explicit textual information regarding whose ground it was. It took the form of promises, warnings, if not threats that the area will be protected by force. But stronger than those words were images that complemented them. In the above mentioned mural (Fig. 1) the text seems purely informative, however, the compositional modality ${ }^{17}$ adds rhetorical force to its message. The outsize scale of the letters overwhelms the onlooker, imitating an effect of shouting. ${ }^{18}$ The deictic "now" and the verb "are" in the present tense are framed by two red fists, thereby drawing the spectator's attention to his or her presence in this particular place and time. The hands seem ready to strike, their colour connotes aggression. This is emphasised by the figure of the masked gunman in lower left corner

17 G. Rose, Visual Methodologies: An Introduction to the Interpretation of Visual Materials, London, Thousand Oaks \& New Delhi: Sage Publications, 2001, pp. 16-17.

18 In "Ancient Egypt and Materiality of Writing” Jan Assmann discusses how features of scripts such as size can function as equivalents to features of delivery of oral messages (in: H.U. Gumbrecht, K.L. Pfeiffer (eds.), Materialities of Communication, transl. W. Whobrey, Stanford: Stanford University Press, pp. 15-31). 
of the image. This combination of word and image conveys a warning, if not a threat. Hooded men holding guns, frequently directing their gaze and weapons at the viewers, represented in loyalist murals had a chilling effect on us. The juxtaposition of their pictures with the British flags, Northern Ireland coat of arms complete with crown and supporters, the Red Hand of Ulster emblem, with the Latin motto "Quis separabit", and acronyms or names of organisations such as UFF (Ulster Freedom Fighters), UVF (Ulster Volunteer Force), UDA (Ulster Defence Association) imparted an impression of ruthless power drawn from the authority of the state and long history going back to the legendary times (Fig. 2). Forker and McCormick argue that these visual components activate mythomoteurs of the Golden Age myth, connoting ideas of victory and military valour. ${ }^{19}$ The same visual components also feature in loyalist commemorative murals devoted to members of the paramilitary organisations killed during the Troubles and afterwards, intended to create an air of heroism (Fig. 3 and 4).

But to an unengaged audience such as tourists this verbo-visual rhetoric can be off-putting. There is some incidental evidence that our response was a pretty typical reaction. In an article about first-time visitors from the South describing their experience of Northern Ireland two Dublin women comment how they were positively surprised by safety in Belfast city centre at night, and how they were "both impressed and shocked by the murals" they saw on "a black-taxi tour of the working-class areas most affected by the Troubles. They find the artwork more aggressive in the loyalist areas, full of men in balaclavas carrying menacing-looking weapons, whereas in republican districts there are more small memorial gardens, commemorating everybody from Bobby Sands to innocent children killed in the violence." 20

If the loyalist murals were intended to advertise the cause of those who painted or commissioned them, they did so not through clever persuasion but through warnings and threats. Admittedly, some republican murals also represented gunned men, and even sometimes women (but their compositional styles differed, which will be discussed in more detail below). Some researchers stress that in fact such murals were used rather as a means of disciplining respective communities, whose wide majority showed reluctance to the use of violence. ${ }^{21}$ With the changing atmosphere of the post-conflict time even the more radical loyalists have adjusted their visual rhetoric to slightly more moderate, sanitised style. For example, the mural commemorating the death of Stevie "Top Gun" McKeag, a member of a loyalist paramilitary organisation UDA ${ }^{22}$ who "was associated with at least 12 murders before he died of a drug

19 M. Forker, J. McCormick, "Walls of history...", pp. 428-435.

20 A. Pollack, "Border crossings: First-time visitors describe their experience of Ireland North and South", The Irish Times, 26.07.2014.

21 G. Goalwin, "The art of war: Instability, insecurity, and ideological imagery in Northern Ireland's political murals, 1979-1998", International Journal of Politics, Culture, and Society, vol. 26(3), September 2013, p. 190; B. Rolston, Drawing Support 3, p. xi.

22 UDA stands for Ulster Defence Association; it was the largest of the loyalist paramilitary organisations in NI, proscripted in 1992; for more details see Abstracts on Organisations - ' $U$ ', the CAIN Project, University of Ulster, http://cain.ulst.ac.uk/othelem/organ/uorgan.htm\#uda. 
overdose in 2000, ${ }^{, 23}$ originally used to depict him in a baseball cap, stereotypically reminiscent more of a street thug. The refreshed image reproduced in Figures 3 and 4 , which appeared in 2016 much to public uproar, ${ }^{24}$ represents him in a uniform and military beret in the serene, blue background, a symbolic heaven. A large, highly elaborate coat of arms with the Union Jack, embellished with flags, and a textual banner: "Remember with Pride", intersected with the red poppy, create a picture reminiscent of World War I and II heroes. Even though the site still features gunmen aiming at the spectators, they have been relegated to a low wall adjacent to the gable wall. Consequently, the originally more aggressive tone of the image has been mitigated.

Interestingly, the article in The Belfast Telegraph reporting on the appearance of restyled McKeag mural contains a photo of an apparently equivalent mural depicting a dead republican fighter Martin Meechan with a rifle, as if to counterbalance the argument about "honouring one of the most notorious terrorists of the Troubles." 25 Admittedly, the IRA man is holding the weapon, yet he is directing it slightly to the right of the spectator, as if aiming it at someone standing beside him, thus protecting the spectator rather than threatening him or her. This little nuance indicates how savvy republicans are in their use of the verbo-visual rhetoric.

Such restylings as that of McKeag's mural may be motivated by the post-conflict atmosphere created by twenty years of generally non-violent coexistence of the two communities, enhanced by public and grass root initiatives to use street art to change attitudes and spaces into more amiable ones. ${ }^{26}$ The results are murals promoting peaceful lifestyle choices, inspiring pride in the working class contribution to the development of local industry, underlying what both sides have in common, and featuring symbolic representations of hope and peace (Fig. 5, 6, 7). The images presented below are a modest sample of photographs of contemporary murals collected by my colleague and coeditor of this issue, Leszek Drong, during his recent field trip to Belfast. ${ }^{27}$ The whole collection featuring nearly 200 items testifies that the range and style of Ulster street art is changing into more aesthetic, less politicised expression, even though murals can still hint at social issues (see, for example, Fig. 8 and 9). It also suggests that street art is flourishing in most unexpected locations, arguably catering for the needs of curious tourists.

23 R. Black, "Fury at new Belfast mural of UDA mass murderer Stephen McKeag", The Belfast Telegraph, 22.09.2016.

24 Ibidem.

25 Ibidem.

26 Some rather unpopular attempts were already undertaken in the 80 's by authorities who commissioned student artists to paint murals in dilapidated areas to "brighten them up" (D. Lisle, "Local symbols...", pp. 36-37). Contemporary initiatives involve local programmes such as Alternatives, EU programmes, and the UN Peace Day Campaign.

27 I gratefully acknowledge prof. Leszek Drong for providing me with this material, and for permission to reproduce the photos in this article. 
Katarzyna Bazarnik



Fig. 5

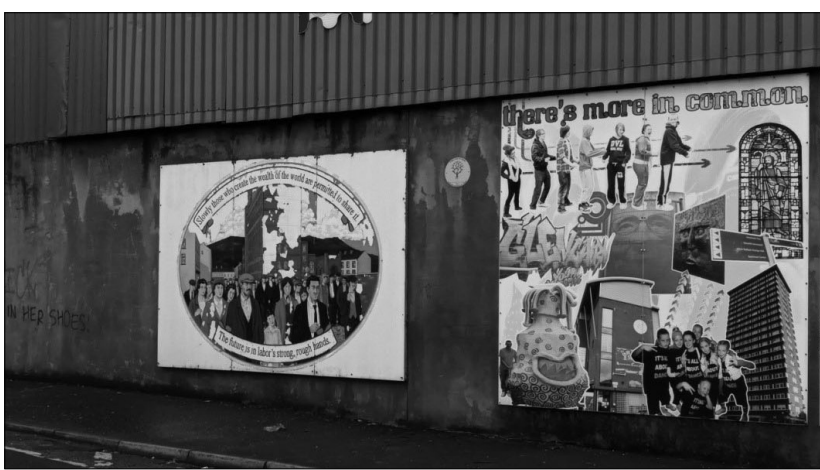

Fig. 6

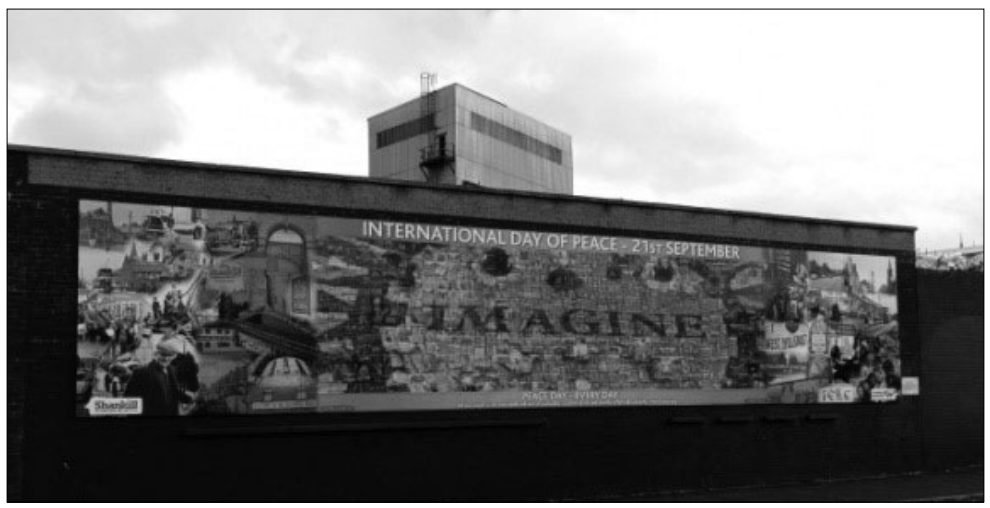

Fig. 7

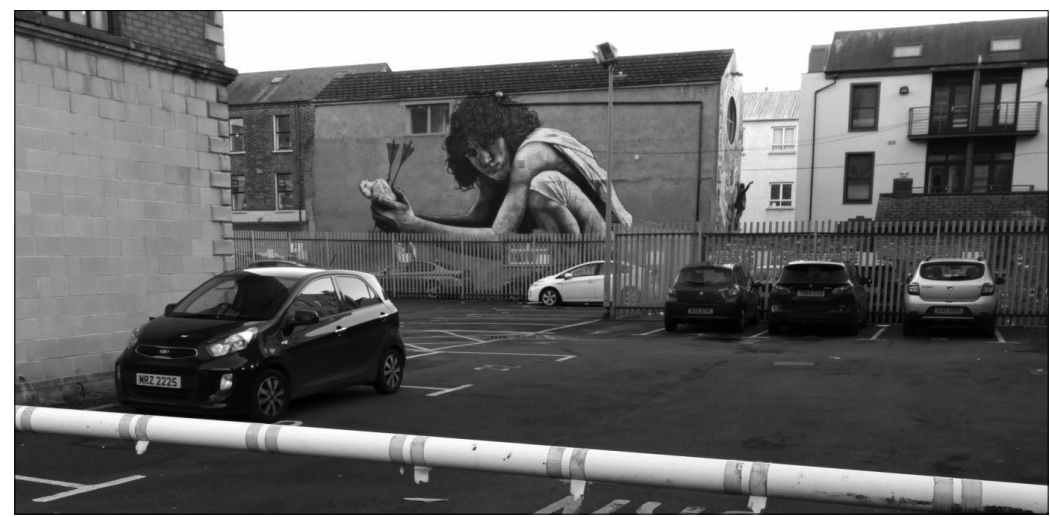

Fig. 8 


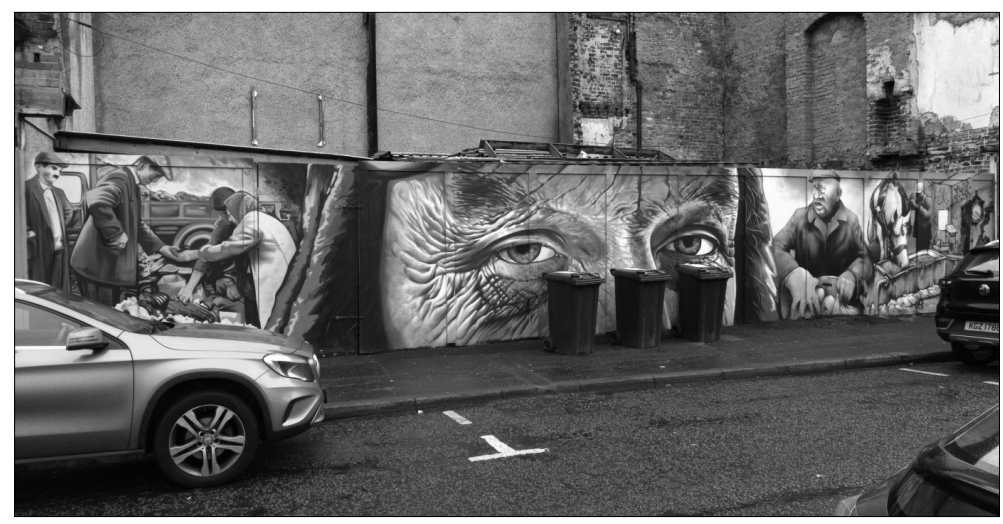

Fig. 9

\section{A Look Back}

Of course, the original target audience of the murals were not tourists at all, but local people, deeply divided by a history of struggle for land and power, and visions of a future. The conflict between the present day loyalists, determined to remain part of the United Kingdom, and nationalists, in favour of the country to join the Republic of Ireland goes back to the middle ages, and then the Ulster Plantation of $17^{\text {th }}$ century, when settlers from Scotland and England were offered land confiscated from the local Irish inhabitants. Since then Ulster has been home to a considerable Protestant community, which differed and wanted to differentiate themselves further from Catholics. Part of that process entailed commemorating historical events, such as the battles of the Boyne during the Jacobite War of 1688-1745, or the Battle of the Somme during World War I, mythologised in popular memory. ${ }^{28}$ Murals turned out to be an efficient tool for this purpose. Their history begins in the early $20^{\text {th }}$ century, when Jim McClean painted "King Billy" on horseback on a wall in Beersbridge Road in Belfast as part of preparations for celebrating the $12^{\text {th }}$ of July, when the notorious Orange Marches take place. With time it has become one of the iconic images featured in unionist murals. ${ }^{29}$ The Protestant community added them to banners, arches and other components of visual folklore connected with commemorations of the Battle of Boyne (1690), in which William of Orange defeated King James and took over the English throne. That is why in the first half of the $20^{\text {th }}$ century murals included

28 M. Forker, J. McCormick, "Walls of history...”, especially pp. 428-429. Cf. also R. Barthes' classic work Mythologies (1972), sel. and transl. A. Lavers, New York: Hill \& Wang, 1995.

29 M. Forker, J. McCormick, "Walls of history...", p. 424; also watch The ISIS Magazine (Oxford), 18.01.2015, https://www.youtube.com/watch? $\mathrm{v}=0 \mathrm{kZUGvJX3zA}$ [access: 3.03.2018]. 
mainly historical scenes depicting military events in which Protestants fought against Catholics. As Gregory Goalwin argues, by presenting the former in a positive light, murals contributed to the creation of "a powerful narrative, inventing a tradition" and constituted part of a unionist cultural policy to justify and assert their rightful, historical presence in Northern Ireland. ${ }^{30}$

For many years, practically until 1980, all murals were the unionist or loyalist murals. Nationalist practice of mural art began later and stemmed from graffiti, due to the fact that this group enjoyed much less freedom in the use of public space. They resorted to graffiti, a form of expression to be found in public spaces, which is used to communicate "political or social discontent," or "opinions that are insufficiently addressed by those in power and society in general." ${ }^{31}$ Its origin can be possibly traced as far back as antiquity, since images combined with brief texts drawn or scratched on walls have been found in ancient cities excavated by archaeologists. ${ }^{32}$ Graffiti appears in environments where access to mass media and other forms of social communication are denied to those who want to convey messages, sentiments, opinions, attitudes and desires deemed too controversial to appear in public discourse. ${ }^{33}$ In this capacity murals are also evidence for as well as part of struggle for control of public space.

Until the early 80's nationalists had very limited possibilities even to use that space. It was simply unimaginable that they could visually mark their presence outside ghetto-like enclaves. ${ }^{34}$ Neil Jarman reports that in the 1970 two men were sentenced to six months in prison for painting the Irish tricolour flag, and in the early 80 's a teenager was shot by a policeman allegedly mistaking his brush for a gun. ${ }^{35}$ It was after the Hunger Strike of 1981 that the first republican murals appeared. Supposedly, it was Bobby Sands who suggested painting graffiti to inform the public about the strike, to ensure wider support for the striking inmates, and to exert pressure on authorities. No wonder that after his death, which provided nationalists with a contemporary martyr to their cause, he was commemorated in numerous murals, often in company of other hunger strike victims. Since then his portrait in Sevastopol Street, Falls, Belfast, has become one of the permanent republican murals, regularly renovated, and repainted, with occasional, minor modifications to the design of its frame (Fig. 10).

30 G. Goalwin, "The art of war...", p. 201.

31 S. Žuvela, "Graffiti: A form of international communication”, CM: Communication and Management Quarterly 2012, vol. 23(7), p. 23.

32 One of the earliest known graffiti or a proto mural comes from the $2^{\text {nd }}$ or $3^{\text {rd }}$ century A.D. Rome. It shows a man worshipping a crucified donkey, accompanied by the words: Alexamenos worships God. See D. Gross, T.D. Gross, "Tagging: Changing visual patterns and the rhetorical implications of a new form of graffiti”, Et Cetera: A Review of General Semantics 1993, vol. 50(3), np.

33 S. Žuvela, Graffiti..., p. 23.

34 B. Rolston, Drawing Support 3, p. v.

35 N. Jarman, Painting Landscapes..., np. 


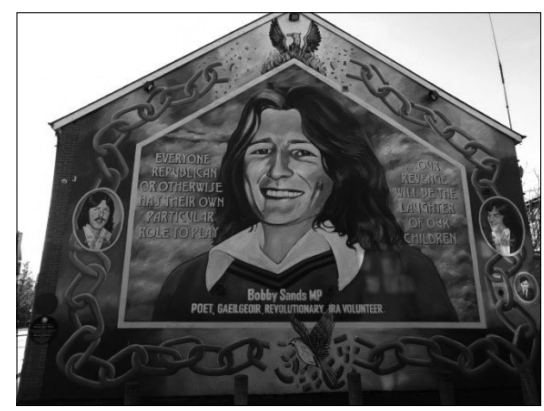

Fig. 10

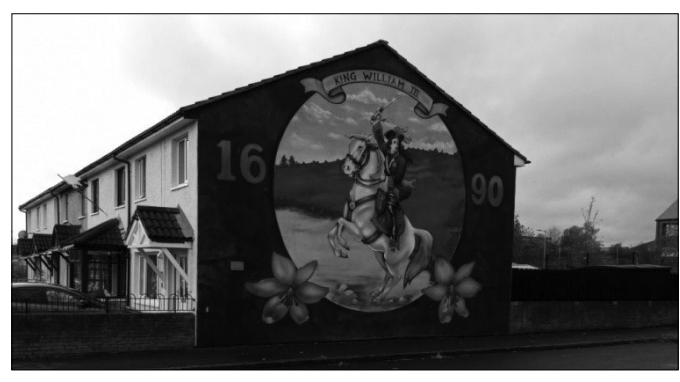

Fig. 11

Gradually simple graffiti evolved into full scale murals. ${ }^{36}$ At first republicans eagerly resorted to mythomoteurs of military struggle, depicting gunmen in fight, and delayed victory in representations of Easter Rising of 1916. But they quickly realised that such images were counterproductive to their desired effect. Instead, they switched to motifs of suffering, tragedy, massacre, rebirth and renewal, especially that "mural painting was encouraged as part of the new West Belfast Festival." ${ }^{37}$ Even if armed IRA members were also portrayed in republican murals, the visual style was different from the anonymous, masked figures in the loyalist images. They are realistic portraits of men in everyday clothes, with their rifles directed upwards or to the side, away from the spectator. Their gazes are thoughtful, if not melancholic, or they smile amiably at the beholder. The scenes are enclosed in Celtic knot braided ornaments, frequently disrupted by a flying bird breaking free from the frame. Unlike loyalist murals, republican ones also occasionally feature women involved in protests and even fight. ${ }^{38}$

\section{Conclusion: the Final Look}

Carrying out extensive study of historical materials and interviews, Maximilian Rapp and Markus Rhomberg found out that "[m]irroring first masked gunmen and IRA symbols like loyalists still do, the offensive propaganda strategy changed continuously to messages, which were absorbed by the recipients more subconsciously. Murals about Celtic tradition, Irish heritage or Gaelic history were painted in broad variety but [they] should transport nationalist ideals and future goals beyond the impressive artworks." They conclude with an observation that "the mainstream republican movement flows today in a much more peaceful way, hence murals have

36 B. Rolston, Drawing Support 3, p. v.

37 N. Jarman, Painting Landscapes..., np.

38 For such images see, for example, B. Rolston, Drawing Support 3, pp. 18-21. 
changed dramatically in style and now project a new image for the post-Agreement republican ethos." 39

As discussed above, it seems that twenty years of post-conflict precarious peace has enabled loyalists to modify their visual style, too, as evidenced by Stevie "Top Gun" McKeag's case. Though it may be argued (as it has been), that this is merely a superficial change, this seems to indicate that blatantly aggressive verbo-visual rhetoric is much less acceptable today. And this is not the only change in the landscape of the city. Other murals considered offensive to the other side of the conflict have been repainted in collaboration with the local communities. For example, a historical mural in Hopewell Crescent showing the persecution of Protestants from the hands of Catholics in 1641 rising has been replaced with the iconic King Billy, as a more acceptable, and less provoking image (Fig. 11).

Much has already been written about murals as an expression of sectarian identity. It has been analysed how murals have both expressed and shaped narrowly conceived, imaginary communities, and how they have served in political debates. Their function and potential to re-shape identities and realities have been also described in the literature of the subject..$^{40}$ In this capacity murals have become a public medium not only for expressing sectarian, political messages, but also for flagging public presence of a class of "social underdogs" who posed themselves as heroes and martyrs, as special and distinct among the mass of "ordinary" folk who wanted to be left in peace. Since murals belong to a set of social practices involved in identity formation for various ethno-national groups,${ }^{41}$ the changes signalled in this article may indicate a transformation of sectarian identities towards more open mindsets. It can be argued that "political" tourism in the aftermath of the Good Friday Agreement and the ongoing efforts to sustain the peace processes have also contributed to this change.

Moreover, the new type of audience for the murals has prompted their transferral to several websites that advertise them as a tourist attraction. The Culture Trip: Europe: Northern Ireland, for example, explains that "Throughout the 20th century, Northern Ireland has had a complicated political history. While the region is vibrant and peaceful today, just over 40 years ago, Belfast was a city in civil war. To learn more about this period of history, wander the streets to take in the sights of colourful murals depicting this time." ${ }^{\prime 2}$ Tourists visiting the city are encouraged to read them

39 M. Rapp, M. Rhomberg, "The importance of Murals during the troubles: Analysing the republican use of wall paintings in Northern Ireland," [in:] D. Machin (ed.), Visual Communication (Handbooks of Communication Science), Berlin \& Boston: De Gruyter, 2014, p. 694.

40 For selected sources see the references section of this article.

${ }^{41}$ Rogers Brubaker qtd. in G. Goalwin, "The art of war...", pp. 190-191. See also M. Forker, J. McCormick, "Walls of history...", pp. 425-427.

42 N. McGovern, "24 Belfast Murals You Need to See", The Culture Trip, 31.01.2017, https://theculturetrip.com/europe/united-kingdom/northern-ireland/articles/24-belfast-murals-you-need-to-see/. This interactive map gives you an idea of the scope of their presence in the city. The colours mark their political affiliations, while the distribution of pointers shows how the city has been divided 
as a kind of "distributed verbo-visual memoir" of the city's troubled past that strive to present a more nuanced, less militant and militarist narrative about it. In the remediation processes murals lose their site-specific quality, radically changing their social and material modalities. ${ }^{43}$ They become digital objects circulating freely in the cyberspace, displayed in many different websites where non-sectarian, consensual discourse can be further developed and practiced.

\section{References}

Assmann, J., “Ancient Egypt and the Materiality of the Sign”, [in:] H.U. Gumbrecht, K.L. Pfeiffer (eds.), Materialities of Communication, transl. W. Whobrey, Stanford: Stanford University Press, 1994, pp. 15-31.

Barry, D., "Belfast journal; Murals of 'Troubles' Draw Passions, and Tourists”, The New York Times, 12.09.2000, https://www.nytimes.com/2000/08/12/world/belfast-journal-murals-of-troubles-draw-passions-and-tourists.html [access: 4.09.2018].

Barthes, R., Mythologies (1972), sel. and transl. A. Lavers, New York: Hill \& Wang, 1995.

Black, R., "Fury at new Belfast mural of UDA mass murderer Stephen McKeag", The Belfast Telegraph, 22.09.2016, https://www.belfasttelegraph.co.uk/news/northern-ireland/fury-at-new-belfast-mural-of-uda-mass-murderer-stephen-mckeag-35068438.html [access: 4.12.2018].

Boal, F., Douglas, N., Integration and Division: Geographical Perspectives on the Northern Ireland Problem, London: Academic Press, 1982.

CAIN Web Service, Conflict and Politics in Northern Ireland, University of Ulster, http://cain. ulst.ac.uk/index.html [access: 4.03.2018].

Calder, S., Gerry, M., "48 hours in Belfast, Northern Ireland”, The Independent, 28.10.2006 (https://www.independent.co.uk/travel/48-hours-in/belfast-northern-ireland-5331043.html [access: 4.09.2018]).

Forker, M., McCormick, J., "Walls of history: the use of mythomoteurs in Northern Ireland murals", Irish Studies Review 2009, vol. 17(4), pp. 423-465, DOI: 10.1080/09670880903315898 [access: 6.12.2018].

Goalwin, G., "The art of war: Instability, insecurity, and ideological imagery in Northern Ireland's political murals, 1979-1998”, International Journal of Politics, Culture, and Society, vol. 26(3), September 2013.

Gross, D., Gross, T.D., "Tagging: Changing visual patterns and the rhetorical implications of a new form of graffiti”, Et Cetera: A Review of General Semantics 1993, no. 50(3), pp. 251-264. Academic OneFile, https://link.galegroup.com/apps/doc/A14540573/AONE $? \mathrm{u}=$ googlescholar\&sid=AONE\&xid=e9e7bd02 [access: 3.03 .2018 ].

Jarman, N., Painting Landscapes: The Place of Murals in the Symbolic Construction of Urban Space, the CAIN Project, University of Ulster, http://cain.ulst.ac.uk/bibdbs/murals/ jarman.htm [access: 4.09.2018].

between the two populations, and how the non-sectarian murals are trying to influence and lessen this division.

43 G. Rose, Visual Methodologies..., pp. 16-17. 
Lennon, J., Foley, M., Dark Tourism: The Attraction of Death and Disaster, New York: Continuum, 2000.

Lisle, D., Holidays in the Danger Zone: Entanglements of War and Tourism, Minneapolis: University of Minnesota Press, 2016.

Lisle, D., "Local symbols, global networks: Rereading the murals of Belfast", Alternatives: Global, Local, Political, vol. 31(1), January-March 2006, pp. 27-52.

McGovern, N., "24 Belfast Murals You Need to See", The Culture Trip, 31.01.2017, https:// theculturetrip.com/europe/united-kingdom/northern-ireland/articles/24-belfast-murals-you-need-to-see/ [access: 4.03.2018].

Mitchell, W.J.T., What Do Pictures Want? The Life and Love of Images, Chicago \& London: Chicago University Press, 2005.

Nicole, "Black Taxi Tour photo essay", Bitten by the Travel Bug travel blog, 11.11.2011, https:// bittenbythetravelbug.com/political-murals-of-belfast-photo-essay/ [access: 2.12.2018].

Nicole, "First Time in Belfast? 5 Must See Sites", Bitten by the Travel Bug travel blog, 15.06.2012, https://bittenbythetravelbug.com/first-time-in-belfast-five-must-see-sites/ [access: 2.12.2018].

Parker, S.B., "Graves, caves, and refugees: An essay in microhistory", Journal for the Study of the Old Testament 2003, vol. 27(3), pp. 259-288.

Pollak, A., "Border crossings: First-time visitors describe their experience of Ireland North and South", The Irish Times, 26.07.2014, https://www.irishtimes.com/life-and-style/ border-crossings-first-time-visitors-describe-their-experience-of-ireland-north-and-south-1.1877003 ? mode $=$ sample \&auth-failed $=1 \& \mathrm{pw}$-origin $=$ https $\% 3 \mathrm{~A} \% 2 \mathrm{~F} \% 2 \mathrm{Fwww}$.irishtimes.com $\% 2$ Flife-and-style $\% 2$ Fborder-crossings-first-time-visitors-describe-their-experience-of-ireland-north-and-south-1.1877003 [access: 4.09.2018].

Rapp, M., Rhomberg, M., "Seeking a Neutral Identity in Northern Ireland's Political Wall Paintings", Peace Review: A Journal of Social Justice 2012, vol. 24(4), pp. 470-477, http:// dx.doi.org/10.1080/10402659.2012.732455 [access: 5.03.2018].

Rapp, M., Rhomberg, M., "The importance of Murals during the troubles: Analysing the republican use of wall painting in Northern Ireland", [in:] D. Machin (ed.), Visual Communication (Handbooks of Communication Science), Berlin \& Boston: De Gruyter, 2014, pp. 677-697. Researchgate https://www.researchgate.net/publication/268446173_The importance_of_Murals_during_the_troubles_Analysing_the_republican_use_of_wall_ paintings_in_Northern_Ireland [access: 5.03.2018].

Rolston, B., Drawing Support: Murals in the North of Ireland, Belfast: Beyond the Pale Publications, 1992.

Rolston, B., Drawing Support 2: Murals of War and Peace, Belfast: Beyond the Pale Publications, 1995.

Rolston, B., Drawing Support 3: Murals and Transition in the North of Ireland, Belfast: Beyond the Pale Publications, 2003.

Rolston, B., Drawing Support 4: Murals and Conflict Transformation in Northern Ireland, Belfast: Beyond the Pale Publications, 2013.

Rolston, B., official website, https://billrolston.weebly.com/ (n.d.).

Rolston, B., "Prison murals in Northern Ireland: Art and resistance", Social Justice, Uncategorized, 31.03.2014,_http://www.socialjusticejournal.org/?p=2173 [access: 4.03.2018].

Rolston, B., Politics and Paintings: Murals and Conflict in Northern Ireland, London \& Cranbury: Fairleigh Dickinson University Press, 1991. 
Rolston, B., "Selling tourism in a country at war", Race and Class, vol. 37(1), 1.07.1995, pp. 23-40, https://doi.org/10.1177/030639689503700103 [access: 4.09.2018].

Rose, G., Visual Methodologies: An Introduction to the Interpretation of Visual Materials, London, Thousand Oaks \& New Delhi: Sage Publications, 2001.

Sharpley, R., "Shedding light on dark tourism: An introduction", [in:] R. Sharpley, P.R. Stone (eds.), The Darker Side of Travel: The Theory and Practice of Dark Tourism, Bristol, Buffalo, Toronto: Channel View Publications, 2009, pp. 3-22.

Taxi Trax, Official Belfast Taxi Tours Website, http://taxitrax.com/belfast-mural-taxi-tours/ [access: 4.08.2018].

Žuvela, S., "Graffiti: A form of international communication", CM: Communication and Management Quarterly 2012, vol. 23(7), pp. 23-36 [access: 19.02.2018]. 